\title{
Genotypic and Phenotypic Characterization of Fungi in the Fusarium oxysporum Species Complex from Soybean Roots
}

\author{
Margaret L. Ellis, David R. Cruz Jimenez, Leonor F. Leandro, and Gary P. Munkvold
}

Department of Plant Pathology and Microbiology, Iowa State University, Ames 50011.

Accepted for publication 6 June 2014.

\begin{abstract}
Ellis, M. L., Cruz Jimenez, D. R., Leandro, L. F., and Munkvold, G. P. 2014. Genotypic and phenotypic characterization of fungi in the $\mathrm{Fu}$ sarium oxysporum species complex from soybean roots. Phytopathology 104:1329-1339.

Isolates in the Fusarium oxysporum species complex (FOSC) from soybean range from nonpathogenic to aggressive pathogens causing seedling damping-off, wilt, and root rot. The objective of this research was to characterize the genotype and phenotype of isolates within the FOSC recovered predominantly from soybean roots and seedlings. Sequence analyses of the translation elongation factor $(t e f 1 \alpha)$ gene and the mitochondrial small subunit (mtSSU), polymerase chain reaction restriction fragment length polymorphism (PCR-RFLP) analysis of the

were conducted for 170 isolates. Vegetative compatibility (VC) tests were conducted for 114 isolates. Isolate aggressiveness was tested using a rolled towel assay for 159 isolates. Phylogenetic analysis of the tef $1 \alpha$ and $\mathrm{mtSSU}$ and PCR-RFLP analysis of the IGS region separated the FOSC isolates into five clades, including $F$. commune. Both mating type loci, MAT1-1 or MAT1-2, were present in isolates from all clades. The VC tests were not informative, because most VC groups consisted of a single isolate. Isolate aggressiveness varied within and among clades; isolates in clade 2 were significantly less aggressive $(P<0.0001)$ when compared with isolates from the other clades and $F$. commune. The results from this study demonstrate the high levels of genotypic and phenotypic diversity within the FOSC from soybean but further work is needed to identify characteristics associated with pathogenic capabilities.
\end{abstract} intergenic spacer (IGS) region, and identification of the mating type loci
Several species of Fusarium have been associated with soybean (Glycine $\max$ (L.) Merr.), with many species causing seed and seedling diseases, root rot, and vascular wilt $(6,9,10,13,14,24$, $33,44,47)$. Fusarium oxysporum Schltdl. is the most common species isolated from soybean roots in Iowa $(14,44)$ and other soybean-producing regions in North America $(9,24)$. F. oxysporum is known to consist of multiple "cryptic species" and, as such, it is often referred to as the "Fusarium oxysporum species complex" (FOSC). In a recent study (13), significant variation in aggressiveness was observed among isolates within the FOSC collected from soybean roots from Iowa; some isolates caused severe root rot, others caused damping-off, and some caused little or no disease. F. commune K. Skovg., O'Donnell \& Nirenberg (46), previously within the FOSC, has been recognized as a pathogenic component of the FOSC on Iowa soybean (16). Isolates of $F$. commune are morphologically indistinguishable from other isolates within the FOSC. Therefore, the frequency at which this species is associated with soybean is unclear, and previous studies may have misidentified $F$. commune for $F$. oxysporum. The results from these studies demonstrate the importance of additional work needed to characterize the genotype and phenotype of isolates in the FOSC collected from soybean.

Within the FOSC, host-specific formae speciales have been described for over 150 hosts (7). Two formae speciales of $F$. oxysporum have been reported to cause wilt in soybean. $F$. oxysporum f. sp. vasinfectum race 2, which causes wilt of cotton (Gossypium hirsutum L.), was first reported as a wilt pathogen of

Corresponding author: G. Munkvold; Email address: munkvold@iastate.edu

* The $\boldsymbol{e}$-Xtra logo stands for "electronic extra" and indicates that the online version contains one supplemental table.

http://dx.doi.org/10.1094/PHYTO-02-14-0043-R

(c) 2014 The American Phytopathological Society
'Yelredo' soybean (6). Later, F. oxysporum f. sp. tracheiphilium race 1, which causes wilt of cowpea (Vigna unguiculata (L.) Walp.), was also found to cause wilt in 'Cobb' and Yelredo soybean (47). Symptoms of soybean wilt usually appear midseason during hot weather $\left(28^{\circ} \mathrm{C}\right)(33)$, and include yellowing and defoliation of leaves and brown to black discoloration in the vascular tissue of the stem (33).

Root rot and seedling disease can also be caused by $F$. oxysporum. Disease is favored by cool temperatures $\left(14\right.$ to $\left.23^{\circ} \mathrm{C}\right)$ and saturated soils during the time of planting, followed by hot and dry weather conditions $(17,33)$. Symptoms include pre- and postemergence damping-off, water-soaked lesions on the stems, stunting, chlorosis and necrosis of cotyledons, wilting, and brown to black root rot in both the lower taproot and lateral roots, with cortical decay or vascular discoloration $(8,33)$. Formae speciales have not been identified for $F$. oxysporum isolates causing seedling disease and root rot in soybean.

Previous research has identified four major clades within the FOSC $(39,40)$ but only one strain from soybean was included in these studies; this isolate was placed in clade 2. This grouping was based on gene sequence information from two genes, the translation elongation factor $($ tef $1 \alpha)$ and the mitochondrial small subunit (mtSSU). These two genes have proven to be useful for distinguishing among members of the FOSC, and studies into genetic diversity within this complex have involved analysis of one or both of these genes in isolates from lettuce (Lactuca sativa L.) (32), maize (Zea mays L.) (37), banana (Musa spp.) $(19,39)$, cotton (46), chickpea (Cicer arietinum L.) (23), and other sources $(7,27,38,40)$. Another region that has been used to identify haplotypes of $F$. oxysporum is the intergenic spacer (ISG) region, through the use of partial or full sequences $(4,19,20,32,38,40)$, or polymerase chain reaction restriction fragment length polymorphisms (PCR-RFLP) $(2-4,19,52)$.

Vegetative compatibility (VC) is another tool used to define relationships among members within the same formae speciales, 
and a standard numbering system for vegetative compatibility groups (VCGs) already exists for this complex (26). Studies have shown that isolates belonging to the same VCG typically possess very similar or identical multilocus haplotypes; therefore, they can be good predictors of genetic similarity. Because VCGs cluster isolates by genetic similarity, they can be useful in predicting phenotypic characteristics such as pathogenicity, as is the case in studies from chickpea $(35,58)$, carnation, and lily (7).

The purpose of the present study was to assess genotypic diversity among isolates of $F$. oxysporum collected predominantly from soybean roots and seedlings, and to determine how the genotypic variation relates to isolate aggressiveness. The information provided from this study will be important for understanding the diversity of this fungus in relation to soybean and will provide valuable information for developing better management strategies for soybean root rot and seedling pathogens. No previous studies have explored genetic diversity within the FOSC from soybean. Therefore, the objectives of this research were to (i) complete a phylogenetic analysis of the tef $1 \alpha$ and $\mathrm{mtSSU}$ genes for 170 soybean isolates from Iowa and surrounding states, (ii) develop a quick and easy method to determine lineage of soybean isolates using PCR-RFLP analysis of the IGS region, (iii) identify the mating type loci of all isolates, (iv) define VCGs for soybean isolates collected from soybean roots and seedlings, and (v) relate these characteristic to isolate aggressiveness.

\section{MATERIALS AND METHODS}

Fungal isolates. In all, 170 isolates were collected from soybean in nine states in the United States. A majority of isolates $(n=$ 128) used in this study were collected from Iowa during a 3-year survey from 2007 to 2009 that assessed Fusarium spp. diversity and frequency from soybean roots (14). Briefly, the isolates of $F$. oxysporum from the previous study (14) were from 74 fields in 55 counties across Iowa and were collected at V2 to V5 or R2 to R4 growth stages, as defined by Pedersen (41). Roots were rinsed for 10 min under running tap water to remove soil and debris from the field. Isolations were made from both symptomatic and asymptomatic root tissue on an antibiotic-amended Nash Snyder medium $(14,28)$. Single-spore isolations were made and isolates were identified to species based on cultural and morphological characteristics, including macroconidia and microconidia, conidial arrangements, nature of the conidiogenous cells (monophialides for $F$. oxysporum), conidiophore length, production and color of sporodochia on carnation leaf agar, and colony appearance and pigment formation on potato dextrose agar (PDA) (14,28). Other isolates, used in this study, were provided by the American Type Culture Collection (ATCC) Center (Manassas, VA), or by collaborators in other states in the central United States. All isolates used in this study were maintained on silica in the dark at $5^{\circ} \mathrm{C}$.

DNA extraction and sequencing. Isolates were grown for 5 days on PDA at $25^{\circ} \mathrm{C}$ with a 12 -h photoperiod, and the edge of the culture was scraped using a sterile loop. The mycelium and spores were transferred to a 50-ml plastic centrifuge tube (Corning Inc., Tewksbury, MA) containing $25 \mathrm{ml}$ of liquid growth media ( $3 \mathrm{~g}$ of yeast extract, $3 \mathrm{~g}$ of malt extract, $5 \mathrm{~g}$ of peptone, $20 \mathrm{~g}$ of dextrose [36], plus $2 \mathrm{~g}$ of $\mathrm{NH}_{4} \mathrm{SO}_{4}$ in 1 liter of water). The inoculated medium was incubated at ambient temperature for 5 days on an innova 2100 platform shaker (New Brunswick Scientific Co., Inc., Enfield, CT) at $100 \mathrm{rpm}$. Mycelium was harvested by filtration with sterile miracloth (EMD Biosciences Inc., La Jolla, CA), frozen, and lyophilized. DNA from each isolate was extracted using a protocol by Zelaya-Molina et al. (59). The lyophilized tissue ( $\approx 200 \mathrm{mg}$ ) was ground in a porcelain mortar and pestle (CoorsTek, Inc., Golden, CO) with $2 \mathrm{ml}$ of digestion buffer (10 mM Tris- $\mathrm{HCl}[\mathrm{pH} 8$,] $50 \mathrm{mM}$ EDTA, $0.5 \%$ Triton X-100, $0.5 \%$ Tween 20 , and $0.5 \%$ sodium dodecyl sulfate [SDS]), and $800 \mu \mathrm{l}$ of this mixture was added to a sterile 2-ml microcentrifuge tube. Next, $2 \mu \mathrm{l}$ of $20 \mathrm{mg}$ of proteinase K (Ambion, Grand Island, NY) was added to each sample. The samples were vortexed for $30 \mathrm{~s}$ and incubated at $55^{\circ} \mathrm{C}$ for $30 \mathrm{~min}$. After samples were cooled to room temperature, $800 \mu \mathrm{l}$ of chloroform/isoamyl alcohol (24:1, vol/vol) was added to each sample. The samples were mixed by hand for 5 min until the two phases formed an emulsion and centrifuged using an Eppendorf 5415D centrifuge (Hamburg, Germany) at 13,200 rpm for $10 \mathrm{~min}$. The supernant was removed and added to a new sterile 2-ml microcentrifuge tube and the chloroform step was repeated. This supernant was then added to $800 \mu \mathrm{l}$ of isopropanol alcohol and the tubes were placed at $-20^{\circ} \mathrm{C}$ overnight. A DNA pellet was formed by centrifuging samples at $13,200 \mathrm{rpm}$ for $10 \mathrm{~min}$. The isopropanol was carefully discarded and the pellet was washed twice with $70 \%$ (vol/vol) ethanol. Once the pellets were completely dry, $100 \mu \mathrm{l}$ of warm Tris-EDTA buffer (10 mM Tris- $\mathrm{HCl}[\mathrm{pH} 8.0]$ and $1 \mathrm{mM}$ EDTA) was added to the samples. After the pellet completely dissolved, $2 \mu \mathrm{l}$ of $20 \mathrm{mg}$ of ribonuclease A/ml (SigmaAldrich, St. Louis) was added to the tube and incubated at $37^{\circ} \mathrm{C}$ for $30 \mathrm{~min}$. The quality and quantity of DNA was evaluated by measuring the concentration (nanograms per microliter) and $\mathrm{A}_{260} / \mathrm{A}_{280}$ and $\mathrm{A}_{260} / \mathrm{A}_{230}$ ratios in a NanoDrop ND-1000 spectrophotometer (NanoDrop Technologies, Wilmington, DE). DNA was diluted to $10 \mathrm{ng}$ of genomic DNA using nuclease-free water (Ambion).

Sequencing of the 170 isolates was completed for the translation elongation $($ tef $1 \alpha)$ gene and mitochondrial small subunit (mtSSU). A $25-\mu \mathrm{l}$ PCR reaction mix containing $20 \mathrm{ng}$ of genomic DNA, $5 \mu$ of $5 \times$ Colorless GoTaq Reaction buffer (Promega Corp., Madison, WI), $2.5 \mu \mathrm{l}$ of $25 \mathrm{mM} \mathrm{MgCl}_{2}$ (Promega Corp.), $1.5 \mu \mathrm{l}$ of $1.3 \mathrm{mM}$ each dNTP (Fermentas/Thermo Fisher Scientific, Inc., Pittsburg), $0.5 \mu \mathrm{l}$ of GoTaq Taq polymerase (Promega Corp.), $2.5 \mu \mathrm{l}$ each of a 5-pmol concentration of primers, and $9.5 \mu \mathrm{l}$ of sterile water. For amplification of the tef $1 \alpha$ gene, the primers EF-1H and EF-2T were used (39), while the primers MS1 and MS2 were used for the amplification of the mtSSU (54) (Table 1). All PCR assays in this study were performed using an Eppendorf mastercycler nexus PCR thermal cycler. PCR parameters for the tef $1 \alpha$ gene were $94^{\circ} \mathrm{C}$ for $1 \mathrm{~min}$; followed by 35 cycles of a denaturation at $94^{\circ} \mathrm{C}$ for $30 \mathrm{~s}$, annealing at $58^{\circ} \mathrm{C}$ for $45 \mathrm{~s}$, and extension at $72^{\circ} \mathrm{C}$ for $1 \mathrm{~min}$; and a final extension at $72^{\circ} \mathrm{C}$ for $5 \mathrm{~min}$. For the $\mathrm{mtSSU}$, the PCR parameters were $97^{\circ} \mathrm{C}$ for $1 \mathrm{~min}$; followed by 35 cycles of a denaturation at $94^{\circ} \mathrm{C}$ for $35 \mathrm{~s}$, annealing at $52^{\circ} \mathrm{C}$ for $55 \mathrm{~s}$, and extension at $72^{\circ} \mathrm{C}$ for $2 \mathrm{~min}$; and a final extension at $72^{\circ} \mathrm{C}$ for $7 \mathrm{~min}$ (27). Product integrity of the PCR product was analyzed using gel electrophoresis on a $2 \%$ agarose containing 1\% DNA Safe (Applied Biological Materials, Inc., Richmond, BC, Canada). The bands were visualized using the Biorad Gel Doc System and sized using the TriDye 100-bp ladder (New England BioLabs Inc., Ipswich, MA). The PCR product was purified by adding $2 \mu$ of Exosap-IT (USB Corp., Cleveland) to $5 \mu \mathrm{l}$ of $\mathrm{PCR}$ product, and this mixture was incubated at $37^{\circ} \mathrm{C}$ for $15 \mathrm{~min}$ followed by incubation at $80^{\circ} \mathrm{C}$ for $15 \mathrm{~min}$.

The purified PCR amplicons were submitted to the DNA Facility of the Iowa State University Office of Biotechnology in Ames for sequencing with the ABI 3730xl DNA Analyzer (Applied Biosystems, Foster City, CA). The raw sequences for the tef $1 \alpha$ and the mtSSU were aligned and edited using Sequencher 4.10.1 (Gene Codes Corp., Ann Arbor, MI) and submitted to a BLAST search for comparison to known DNA sequences in the National Center for Biotechnology Information (NCBI) (http:// ncbi.nlm.nih.gov) database.

Phylogenetic analyses. Phylogenies were inferred for the tef $1 \alpha, \mathrm{mtSSU}$, and combined dataset (sequence data for both the tef $1 \alpha$ and mtSSU genes). For the final analyses, 39 nucleotide sequences were used, which included representative sequences collected from NCBI GenBank for each of the four clades as 
designated by O'Donnell et al. (40) and for each soybean isolate with a unique sequence (GenBank accessions for the tef $1 \alpha$ [KJ415305 to KJ415326] and mtSSU [KJ415327 to KJ415348] genes). Sequences were aligned using ClustalW (51). For the combined dataset, sequences were concatenated using the Combine function in SNAP Workbench (42). Phylogenies based on maximum parsimony and maximum likelihood were inferred using MEGA 5.2.2 (49), and a Bayesian inference was inferred using MrBayes v. 3.1.2 (21). Heuristic searches for the most parsimonious trees were conducted with 10 random addition replicates and tree-bisection-reconstruction (34) with search level 1 for the maximum parsimony analyses. The best-fit model of nucleotide substitution was determined in MEGA for the maximum likelihood and Bayesian analyses. For the maximum likelihood analyses, the Kimura 2-parameter model (25) plus the $\gamma$ correction for among-site variation $(\mathrm{K} 2+\mathrm{G})$ was used for the tef $1 \alpha$, and the Tamura 3-parameter model (48) plus the $\gamma$ correction for among-site variation $(\mathrm{T} 92+\mathrm{G})$ was used for the mtSSU and the combined dataset. For the maximum parsimony and maximum likelihood analyses, gaps were treated as missing data and relative support for branches was estimated with 1,000 bootstrap replications (18). For the Bayesian analyses, the likelihood parameters settings (lset) number of substitution types $(\mathrm{nst})=2$, with a $\gamma$ distribution (rates $=\gamma$ ) and the number of discrete categories used to approximate the $\gamma$ distribution (Ngammacat) $=6$ was selected for the tefl $\alpha$, mtSSU, and combined dataset. The Bayesian inference trees were constructed using three hot and one cold Markov chain Monte Carlo iterations with 1,000,000 generations with sampling every 100 generations, and the first 250,000 generations were discarded as the chains converged.

RFLP analysis. The IGS region was amplified using the same $25-\mu l$ PCR reaction mix as previously described, with the primers NL11 and CNS1 (54) (Table 1). The PCR parameters for amplification of the IGS region were $95^{\circ} \mathrm{C}$ for $5 \mathrm{~min}$; followed by 35 cycles of a denaturation at $94^{\circ} \mathrm{C}$ for $30 \mathrm{~s}$, annealing at $56^{\circ} \mathrm{C}$ for $60 \mathrm{~s}$, and extension at $72^{\circ} \mathrm{C}$ for $3 \mathrm{~min}$; and a final extension at $72^{\circ} \mathrm{C}$ for $7 \mathrm{~min}$. PCR products were checked for integrity using gel electrophoresis on a $2 \%$ agarose containing $1 \%$ DNA Safe (Applied Biological Materials, Inc.). The bands were visualized using the Biorad Gel Doc System and sized using the TriDye 100-bp ladder (New England BioLabs Inc.). Twenty-eight selected isolates were PCR purified using Exosap-IT (USB, Corp.), sequenced, and aligned as described above. To sequence the complete IGS region $(\approx 2,600 \mathrm{bp})$, nine internal primers (Table 1) were used as described by Mbofung et al. (32). Restriction enzymes for an RFLP analysis were determined from previous studies $(2-4,19,52)$ and from the 28 sequenced isolates, which were analyzed using the NEBcutter V2.0 (53). For all 170 isolates, $5 \mu \mathrm{l}$ of PCR product was added to $2 \mu \mathrm{l}$ of the supplied restriction buffer and digested with $2 \mathrm{U}$ of the following restriction enzymes: AvaI (BmeT110I), ClaI, and XhoI (PaeR7I) (Invitrogen Life Technologies, Corp., Carlsbad, CA) (19). The PCR products were incubated at $37^{\circ} \mathrm{C}$ for 4 to $6 \mathrm{~h}$. The digested PCR product was analyzed by gel electrophoresis on a $3 \% 3: 1$ HRB agarose (AMERSCO Inc., Solon, OH) containing 1\% DNA Safe (Applied Biological Materials, Inc.) for 2 to $3 \mathrm{~h}$ at $150 \mathrm{~V}$ in the RapidRun Agarose Buffer (Affymetrix/USB Inc., Cleveland). The digested fragments were visualized using the Biorad Gel Doc System and restriction sites above $0.2 \mathrm{~kb}$ were sized using the TriDye 100-bp ladder (New England BioLabs, Inc.) and 1-kb plus DNA ladder (Invitrogen Life Technologies, Corp.).

Mating-type analysis. To determine the mating type (MAT) of each isolate, PCR amplification of the MAT idiomorphs in the Gibberella/Fusarium spp. was performed using the same 25- $\mu \mathrm{l}$ PCR reaction mix as previously described, with three sets of primers (Table 1) (57). For amplification of a 1,475-bp fragment from MAT1-1, the primers FMAT1-2p1 and FoMAT1-2p2 were used; for MAT1-2, the primers FMATp1/FoMAT2p2 and FoMAT2p10/FMATp2 were used to amplify a 593- and 229-bp fragments, respectively $(52,57)$. The PCR parameters were $94^{\circ} \mathrm{C}$ for $5 \mathrm{~min}$; followed by 30 cycles of a denaturation at $94^{\circ} \mathrm{C}$ for $1 \mathrm{~min}$, annealing at $64^{\circ} \mathrm{C}$ (FoMAT1-2p1/FoMAT1-2p2), $60^{\circ} \mathrm{C}$ (FoMAT2p10/FMATp2), or $55.5^{\circ} \mathrm{C}$ (FMATp1/FoMAT2p2) for $1 \mathrm{~min}$, and extension at $72^{\circ} \mathrm{C}$ for $1 \mathrm{~min}$; and a final extension at $72^{\circ} \mathrm{C}$ for $7 \mathrm{~min}$. The PCR product was analyzed by gel electrophoresis on a $2 \%$ agarose containing 1\% DNA Safe (Applied Biological Materials, Inc.). The bands were visualized using the Biorad Gel Doc System and sized using the TriDye 100-bp ladder (New England BioLabs).

VC tests. The isolation and characterization of nit mutants were completed as described by Correll et al. (11) for 84 isolates of $F$. oxysporum and 30 isolates of $F$. commune from Iowa. We were not able to produce nit mutants for the remaining 14 isolates from Iowa. Briefly, chlorate-resistant sectors were recovered on a minimal medium containing chlorate at concentrations of 1.5 to $4.0 \%$. The sectors were then transferred to a minimal medium with nitrate as the sole source of nitrogen. Colonies that grew

TABLE 1. Primers used for polymerase chain reaction (PCR), sequencing, and PCR restriction fragment length polymorphism fingerprinting for the translation elongation factor $(t e f 1 \alpha)$ gene, mitochondrial small subunit (mtSSU), intergenic spacer (IGS) region, and mating type loci (MAT1-1 and MAT1-2)

\begin{tabular}{llll}
\hline Primer & Locus & \multicolumn{1}{c}{ Sequence (5' to 3') } & Reference \\
\hline EF-1H & tef1 $\alpha$ & ATGGGTAAGGAAGACAAGAC & O'Donnell et al. (39) \\
EF-2T & $t e f 1 \alpha$ & GGAAGTACCAGTGATCATGTT & White et al. (54) \\
MS1 & mtSSU rDNA & CAGCAGTCAAGAATATTAGTCAATG & White et al. (54) \\
MS2 & mtSSU rDNA & GCGGATTATCGAATTAAATAAC & White et al. (54) \\
NL11 & IGS rDNA & CTGAACGCCTCTAAGTCAG & White et al. (54) \\
CNS1 & IGS rDNA & GAGACAAGCATATGACTAC & Appel and Gordon (4) \\
U46.67 & IGS rDNA & AATACAAGCACGCCGACAC & Mbofung et al. (32) \\
RU46.67 & IGS rDNA & GTGTCGGCGTGCTTGTATT & Mbofung et al. (32) \\
CN61 & IGS rDNA & GGTTCAATTTGATGTCGGCT & Mbofung et al. (32) \\
RCN61 & IGS rDNA & AGCCGACATCAAATTGACC & Mbofung et al. (32) \\
RU3 & IGS rDNA & GTGTGAAATTGGAAAGTCGG & Mbofung et al. (32) \\
RRU3 & IGS rDNA & CCGACTTTCCAATTTCACAC & Mbofung et al. (32) \\
CN34 & IGS rDNA & CCAACACATGGGTGGTACCG & Mbofung et al. (32) \\
IGSF4 & IGS rDNA & CCAGACTTCCACTGCGTGTC & Mbofung et al. (32) \\
CNS12 & IGS rDNA & GCACGCCAGGACTGCCTCGT & Arie et al. (5) \\
FMAT1-2p1 & MAT1-1 & GTTTTGACCGCATTGATTGGACTACC & Arie et al. (5) \\
FoMAT1-2p2 & MAT1-1 & CTACACAACACCCACACTTCTCATCAT & Arie et al. (5) \\
FMATp1 & MAT1-2 & GACCTAGTGCAACAAGAAACAAAAGCGAGTG & Arie et al. (5) \\
FoMAT2p2 & MAT1-2 & GTCACCAGTCGATCAAGGCTCAAC & Arie et al. (5) \\
FoMAT2p10 & MAT1-2 & GAATAGGGAAATGCAAAAATCTGA & Arie et al. (5) \\
FMATp2 & MAT1-2 & AACCCTGTGTCCTTTAACCCTGAGCAT & \\
\hline
\end{tabular}


thinly with no aerial mycelium were transferred to nitrite, ammonium, and hypoxanthine media and characterized as nitl, nit3, or nitM, based on their growth characteristics on the different media $(11,28)$. Complementation tests were completed by the pairing of different nit mutants on nitrate media, and a positive reaction was confirmed by a dense growth of mycelium where anastomosis between two nit mutants occurred, forming a heterokaryon. Pairings were made between different nit mutants of the same isolate, followed by pairings of different isolates within the same clade designated from the phylogenetic analysis. Isolates with positive reactions were determined to be in the same VCG. A representative isolate from each of the VCGs within each clade were then paired with those from other clades. All pairings were repeated at least twice. Isolates from surrounding states were excluded from the analysis based on results from Iowa isolates, because approximately two-thirds of the isolates were incompatible with any other isolate.

Isolate aggressiveness assay. Isolate aggressiveness was determined using a modified rolled-towel assay for 159 isolates (12, 15). Inoculum for each isolate was grown for 10 days on PDA at $25^{\circ} \mathrm{C}$ with a 12 -h photoperiod. Eleven isolates were excluded from the rolled-towel assay, due to a lack of sporulation. Briefly, 10 seeds of the susceptible 'MN1805' (12) were placed on a moistened paper towel and inoculated with $100 \mu \mathrm{l}$ of a $1 \times 10^{6}$ conidial suspension of an isolate. Another moistened paper towel was placed over the inoculated seed, rolled up, and placed vertically in a 25 -liter bucket. There were three replicate towels per isolate. For each isolate, the three towels were placed into an open plastic bag to avoid cross-contamination from the other isolates. Approximately six to eight isolates were randomly assigned to a bucket. A black plastic bag was placed over each bucket and they were placed on a bench at room temperature $\left(\approx 22^{\circ} \mathrm{C}\right)$. Noninoculated checks were included to ensure that other seed pathogens were not present. The experimental design was an augmented randomized incomplete block, with three isolates that were used as checks: FO38 and FO40 (highly aggressive) and FO42 (weakly aggressive) $(12,13)$. Due to time and space constraints, experimental isolates were divided into incomplete blocks of 20 to 43 isolates that were evaluated over six to seven separate days. The check isolates were included in each of the incomplete blocks and were used to estimate the error mean square and the blocking effect (55). There was no significant effect from bucket within the incomplete blocks; therefore, it was not considered a blocking factor in the final analysis. There were three replications for each isolate and the entire experiment was conducted twice. The seedlings were rated 7 days after inoculation by measuring the length of diseased hypocotyl tissue (lesion length in millimeters) and the total plant length (millimeters). Disease severity index (DSI) was calculated by dividing the lesion length by the total plant length and multiplying by 100 (15).

The DSI data were arcsine transformed, because the range of DSI data was $>40 \%$ (30), and analyzed using the PROC MIXED procedure of SAS 9.3 (SAS Institute Inc., Cary, NC). The transformed data for isolates were compared against the check isolates (FO38, FO40, and FO42) using Dunnett's $t$ test at $P=0.05$. This procedure allowed comparison of experimental isolates with check isolates within the incomplete blocks but also took into account the response of check isolates across blocks. Based on the adjusted $P$ value for comparison with the checks, each isolate was grouped into one of three categories: highly aggressive (significantly different from FO42), moderately aggressive, and weakly aggressive (significantly different from FO38 and FO40). The transformed data for the DSI were used to analyze clades from the phylogenetic analysis across all iterations, and mean aggressiveness was compared among clades using contrasts. Clade 4 was excluded from this analysis because there was only one isolate (IL-2-2).

\section{RESULTS}

Sequence and phylogenetic analyses. The final DNA alignments resulted in 557, 687, and 1,244 positions, while 518, 666, and 1,185 bp were constant (gaps were treated as missing data) and used in the final analyses for the tefl $1 \alpha, \mathrm{mtSSU}$, and combined data, respectively. The maximum parsimony analysis for the combined data resulted in three most parsimonious trees (length $=$ 142 , consistency index $(\mathrm{CI})=0.793$, retention index $(\mathrm{RI})=0.957$, and rescaled consistency index $(\mathrm{RCI})=0.759)$. The maximum parsimony, maximum likelihood, and Bayesian inference for the combined data gave similar tree topologies (Fig. 1). Based on this analysis, soybean isolates fell within three of four clades, as designated by O'Donnell et al. (40). In all, 38 isolates grouped with representative isolates from clade 2, 41 isolates grouped with representative isolates from clade 3 , and 1 isolate from Illinois grouped with representative isolates from clade 4 (40). A total of 45 isolates fell into a clade not previously described by O'Donnell et al. (40), designated here as clade 5 . The remaining 45 isolates were identified as F. commune (Table 2; Supplemental Table 1).

The maximum parsimony analysis for the mtSSU resulted in three most parsimonious trees (length $=39, \mathrm{CI}=0.786, \mathrm{RI}=$ 0.971 , and $\mathrm{RCI}=0.763$ ). The maximum parsimony, maximum likelihood, and Bayesian inference for the mtSSU gave similar tree topologies (Fig. 2). There were five unique sequences for the $\mathrm{mtSSU}$, which corresponded to the clade each soybean isolate belonged to from the trees generated from the combined dataset (Table 2). However, clades 1 and 5 and clades 3 and 4 were not as clearly resolved from the trees generated from the mtSSU sequence data (Fig. 2).

The maximum parsimony analysis for the tef $1 \alpha$ resulted in four most parsimonious trees (length $=98, \mathrm{CI}=0.842, \mathrm{RI}=0.960$, and $\mathrm{RCI}=0.808$ ). The maximum parsimony, maximum likelihood, and Bayesian inference for the tef $1 \alpha$ gave similar tree topologies (Fig. 3). Clades 2 and 3 were not as clearly resolved in the trees generated from the tef $1 \alpha$ sequence data. Isolate 268 had a sequence that fell within clades 2 and 3 for the tef $1 \alpha$ but had the same sequence for the mtSSU as other soybean isolates for clade 2 (Fig. 3). Within the previously defined clades, there was sequence variation for the tef $1 \alpha$ among soybean isolates. Clades 2 , 3 , and 5 had five, four, and seven unique sequences for the tef $1 \alpha$, respectively. Within $F$. commune, there were four unique sequences for the tef $1 \alpha$ (Table 2). In Iowa, most isolates from a particular clade had identical sequences for the tef $1 \alpha$ but it was not possible to determine whether there was a dominant sequence for tef $1 \alpha$ for each geographic region.

RFLP analysis. For the PCR-RFLP fingerprinting of the IGS region $(\approx 2.5$ to $2.6 \mathrm{~kb})$, representative isolates from each clade were sequenced, aligned, and then cut with the NEBcutter V2.0 (53) to determine which restriction enzymes might show polymorphisms between clades. The enzymes AvaI, ClaI, and XhoI were chosen based on the NEBcutter results and from previous studies that used these enzymes to characterize genetic variation in $F$. oxysporum f. sp. phaseoli from common bean $(2,52)$. XhoI produced unique banding patterns for most isolates in clades 3 $(1.75$ and $0.75 \mathrm{~kb})$ and 5 (1.30 and $1.20 \mathrm{~kb})$; however, four isolates in clade 5 and 23 isolates in clade 3 did not have any restriction sites for this enzyme. XhoI could not distinguish isolates from clades 2,4 , and $F$. commune (1.25 and $1.25 \mathrm{~kb})$. AvaI produced unique banding patterns for all isolates in clade 3 (1.40 and $0.75 \mathrm{~kb})$ and clade 5 (1.30 and $0.85 \mathrm{~kb})$; clades 2,4 , and $F$. commune (1.30 and $0.95 \mathrm{~kb}$ ) could also not be separated using this enzyme. ClaI could distinguish clade 3 and $F$. commune (1.95 and $0.50 \mathrm{~kb})$ from clade 2 and $5(2.00$ and $0.45 \mathrm{~kb})$, and the one isolate from clade 4 did not have a restriction site with this enzyme. A band of $0.62 \mathrm{~kb}$ was present for isolates of $F$. commune when digested with ClaI but this is likely due to a partial digestion because the restriction site does not exist in the 
sequenced isolates. Seven isolates from clade 2 produced unique banding patterns $(1.5$ and $0.75 \mathrm{~kb})$ from all other isolates when digested with AvaI; these isolates did not have restriction sites for ClaI and XhoI (Table 2; Fig. 2).

MAT analysis. Both MAT loci were present in $F$. oxysporum and $F$. commune isolates collected from soybean, based on amplification of the 1,475-bp fragment for MAT1-1 or 593- and 229-bp fragments for MAT1-2. Representation of both MAT loci was identified in clades 2, 3, and 5. Clades 2 and 3 had 16 and 21 isolates with the MAT1-1 locus and 22 and 20 isolates with the MAT1-2 locus, respectively. The one isolate in clade 4 had the MAT1-1 locus. Clade 5 and $F$. commune were dominated by one

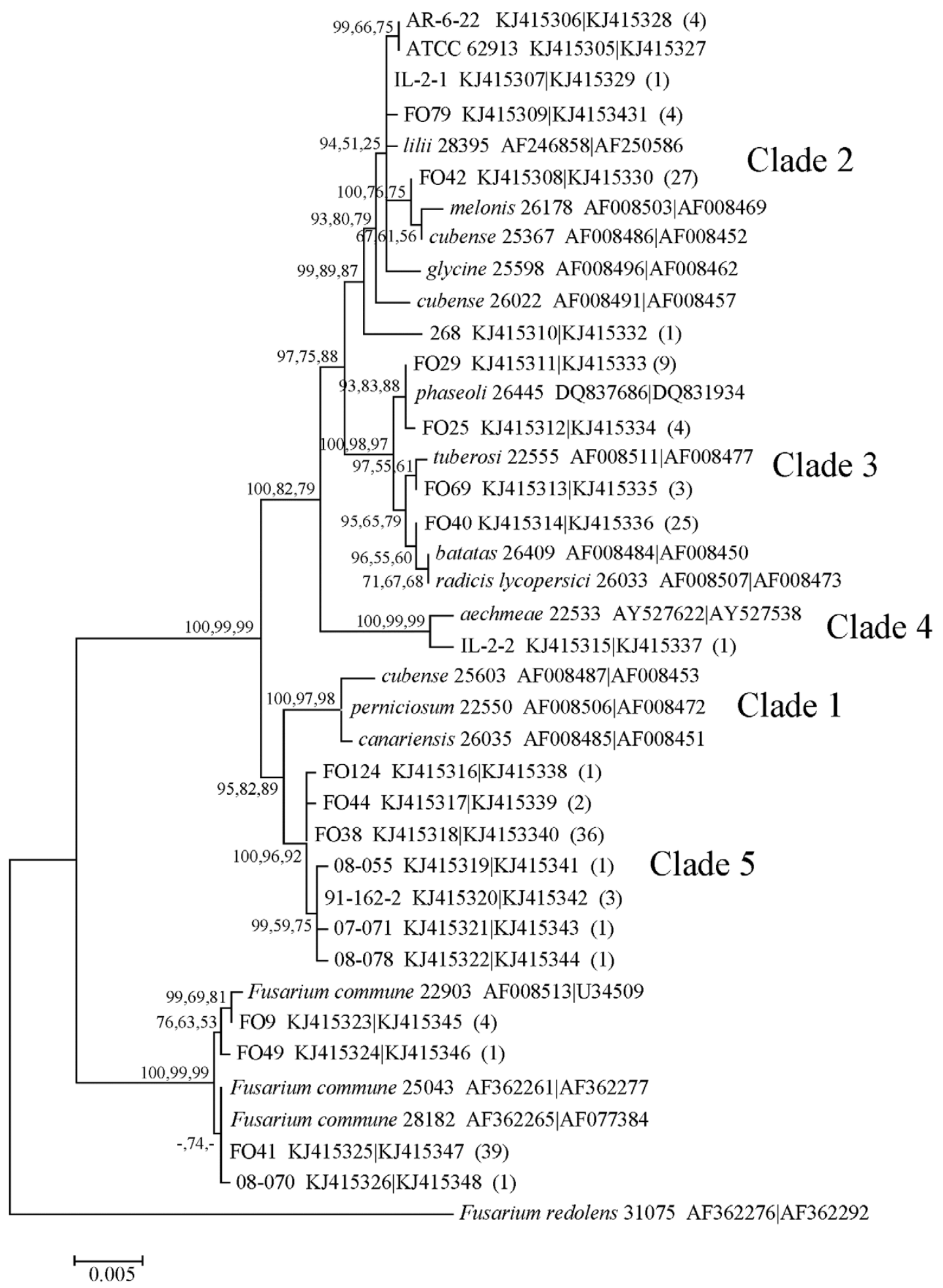

Fig. 1. Maximum likelihood phylogenetic tree of Fusarium oxysporum and F. commune isolates from soybean inferred from the combined translation elongation factor $(t e f 1 \alpha)$ gene and the mitochondrial small subunit (mtSSU) sequence data. Representative sequences collected from the National Center for Biotechnology Information GenBank are followed by their Agricultural Research Service (NRRL) culture collection number. All sequences are followed by their GenBank accessions. The number in parenthesis indicates the number of isolates with the same sequence from this study. The Bayesian posterior probabilities followed by the bootstrap values for the maximum likelihood and maximum parsimony analyses (1,000 replications) are indicated as percentages in that order at the internodes. F. redolens strain NRRL 31075 was used to root the tree. 
MAT. In clade 5, there were 40 isolates with the MAT1-2 locus and 5 isolates with the MAT1-1 locus. In total, 33 isolates of $F$. commune had the MAT1-1 locus and 12 isolates had the MAT1-2 locus (Table 2).

VC analysis. The VC analysis was completed for 22 of 24, 27 of 29, 35 of 36, and 30 of 39 isolates from Iowa for clades 2, 3, 5, and $F$. commune, respectively. Isolates from clade 2 had one VCG with 2 isolates and another VCG with 7 isolates, while the remaining 13 isolates were incompatible with all other isolates. Clade 3 had three VCGs containing 4, 7, and 3 isolates and the remaining 14 isolates were incompatible with all other isolates. Isolates from clade 5 had two VCGs containing 8 and 3 isolates, while the remaining 24 isolates were incompatible with all other isolates. F. commune had four VCGs each containing 2 isolates, and the remaining 22 isolates were incompatible with all other isolates. If isolates were in the same VCG, they were always within the same clade and had identical sequences for the tefl $\alpha$ and mtSSU. However, there seemed to be no pattern based on isolate aggressiveness within VCGs containing more than one isolate, because many groups contained isolates ranging from low to high levels of aggressiveness. There was also no geographical pattern based on VCG. Because the VCG data provided little information based on isolate aggressiveness or geographical location, we did not complete the VCG testing for isolates from other states.

Isolate aggressiveness assay. All isolates were able to infect soybean seedlings but symptom severity varied among isolates. Symptoms ranged from water-soaked lesions that were dark brown and covered a majority or the entirety of seedling to small lesions $\approx 3$ to $10 \mathrm{~mm}$ in length. Based on the arcsine-transformed data for the DSI, there was a significant difference in aggressiveness for the main effect of isolate $(P<0.0001)$. Comparisons with the check isolates (FO38, FO40, and FO42), using the transformed data for DSI were used to group isolates into three categories: high, moderate, and low levels of aggressiveness toward soybean. The mean DSIs for the check isolates were 50.92, 58.98, and 17.62 for FO38, FO40, and FO42, respectively. In all, 59 isolates (including FO38 and FO40) had high levels of aggressiveness, 69 isolates had moderate levels of aggressiveness, and 31 isolates (including the check FO42) had low levels of aggressiveness. The mean DSI ranged from 80.65 to $44.65,47.09$ to 17.92 , and 20.30 to 0.18 for high, moderate, and low levels of

TABLE 2. Diversity in 170 Fusarium oxysporum and F. commune isolates collected from soybean from different U.S. states for the sequence data for the translation elongation factor $(t e f 1 \alpha)$ gene and mitochondrial small subunit ( $\mathrm{mtSSU}$ ), and polymerase chain reaction restriction fragment length polymorphism (PCR-RFLP) fingerprinting of the intergenic spacer (IGS) region, and mating type loci (MAT1-1 and MAT1-2) ${ }^{\mathrm{a}}$

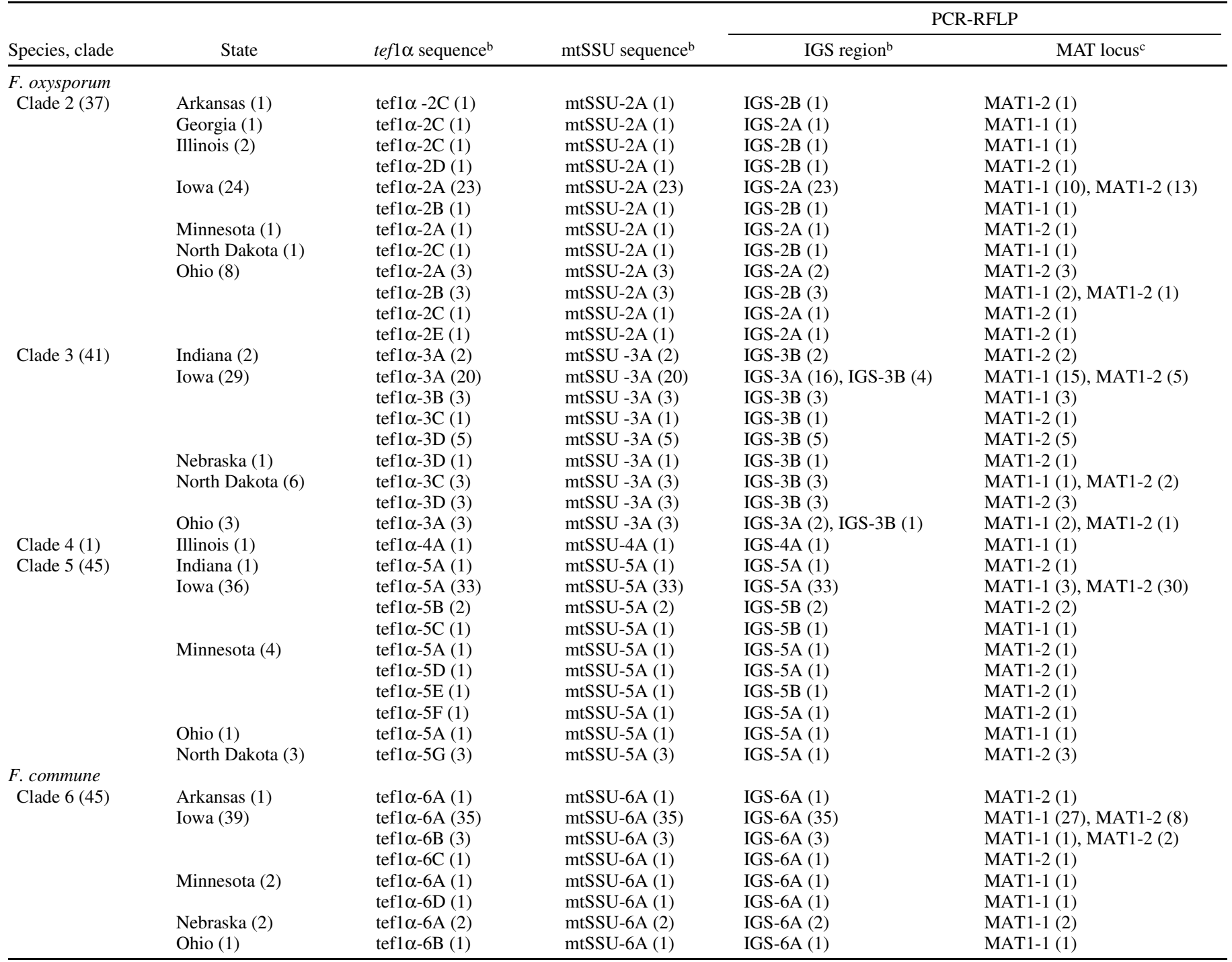

${ }^{a}$ Isolates fall into four distinct clades within the $F$. oxysporum species complex, along with the newly identified soybean pathogen $F$. commune. Numbers in parentheses represent the number of isolates in each group.

${ }^{\mathrm{b}}$ For the tef $1 \alpha$ and $\mathrm{mtSSU}$ sequences and IGS fingerprinting, the number represents the clade and the letter represents a unique pattern within the clade.

${ }^{\mathrm{c}}$ Each isolate has either the MAT1-1 or MAT1-2 mating type locus. 
aggressiveness, respectively. Based on the transformed data for the DSI, there was significant variation in isolate aggressiveness within the three clades of $F$. oxysporum and $F$. commune. However, clade 2 had many isolates that were classified as low in aggressiveness and the mean DSI for clade 2 was significantly less $(P<0.0001)$ than that of the other clades and $F$. commune (Table 3; Fig. 4). Clade 2 had 13 isolates with low levels of aggressiveness and only 7 isolates with high levels of aggressiveness, whereas there were 6,6 , and 5 isolates with low levels of aggressiveness and 14, 20, and 18 isolates with high levels of aggressiveness for clades 3,5 , and $F$. commune, respectively. The average DSI was 29.47 for clade 2 and 36.39, 42.94, and 42.18 for clades 3, 5, and $F$. commune, respectively.

\section{DISCUSSION}

The results from this study provide valuable information on the diversity of $F$ oxysporum and $F$. commune isolates collected from soybean grown in the Midwestern and southeastern United States. We demonstrated that members of the FOSC infecting soybean seedlings and roots vary genotypically and phenotypically. Isolates from Iowa and other states belonged to five clades within

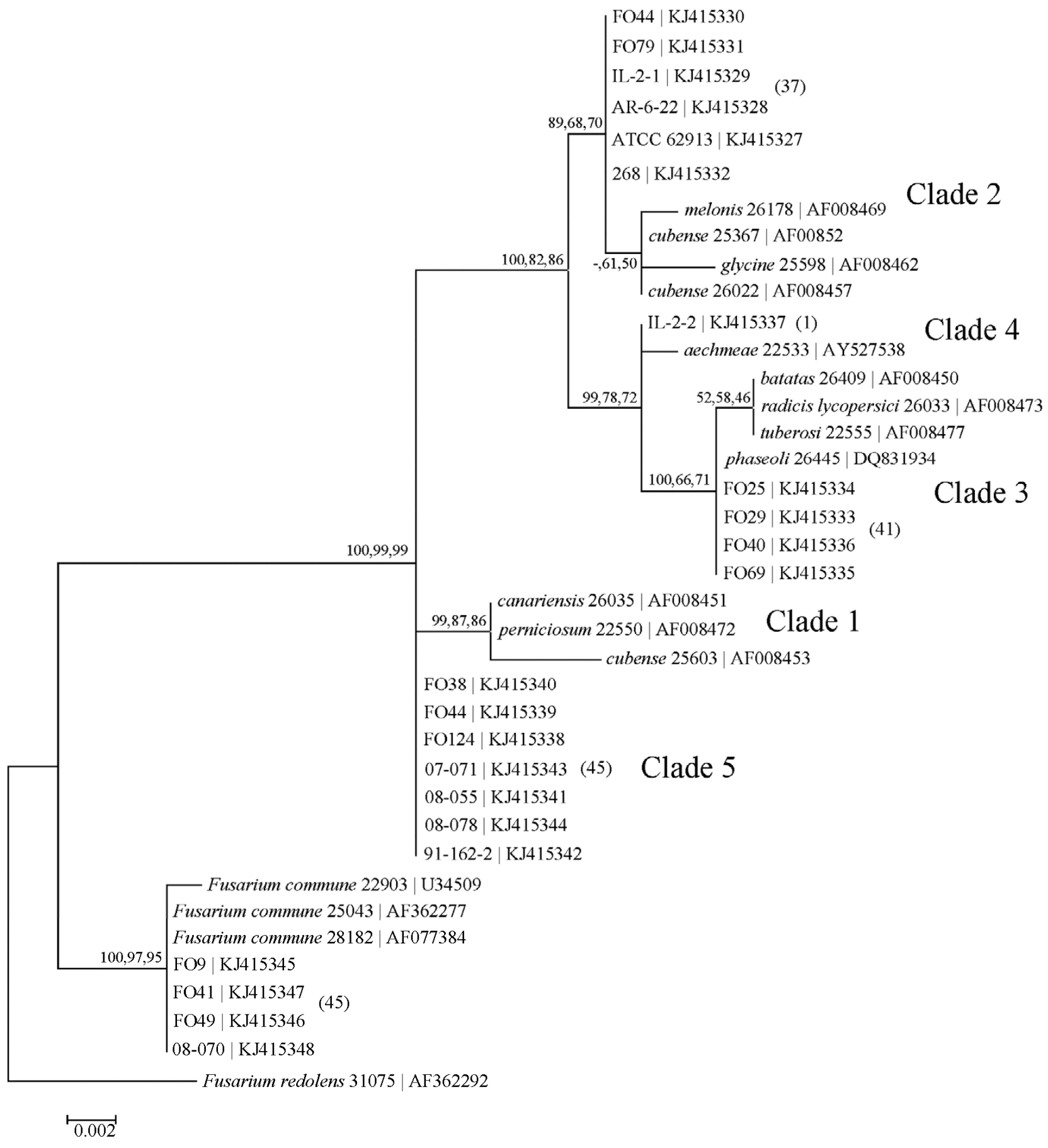

Fig. 2. Maximum likelihood phylogenetic tree of Fusarium oxysporum and F. commune isolates from soybean inferred from the mitochondrial small subunit (mtSSU) sequence data. Representative sequences collected from the National Center for Biotechnology Information GenBank are followed by their Agricultural Research Service (NRRL) culture collection number. All sequences are followed by their GenBank accessions. The number in parenthesis indicates the number of isolates with the same sequence from this study. The Bayesian posterior probabilities, followed by the bootstrap values for the maximum likelihood and maximum parsimony analyses (1,000 replications) are indicated as percentages in that order at the internodes. F. redolens strain NRRL 31075 was used to root the tree. 
the FOSC, including $F$. commune, and vary from highly aggressive to weakly aggressive pathogens to soybean seedlings. In general, there was no clear association between the genotypic characteristics that we assessed and aggressiveness of an isolate. However, it is important to note that clade 2 contained many isolates of low aggressiveness, and the mean aggressiveness of isolates belonging to clade 2 was significantly less $(P<0.0001)$ than that of the other clades of F. oxysporum and F. commune.
The phylogenetic analysis of the tef $1 \alpha$ gene and mtSSU revealed that isolates within the FOSC from soybean are polyphyletic in origin, with soybean isolates belonging to five clades within the FOSC. Three of the clades identified in this study were previously described by O'Donnell et al. (40), while other isolates belonged to a clade that was not previously described (designated here as clade 5), or F. commune, previously part of the FOSC (46) (Figs. 1 to 3). Polyphyletic origins of formae speciales of F. oxy-

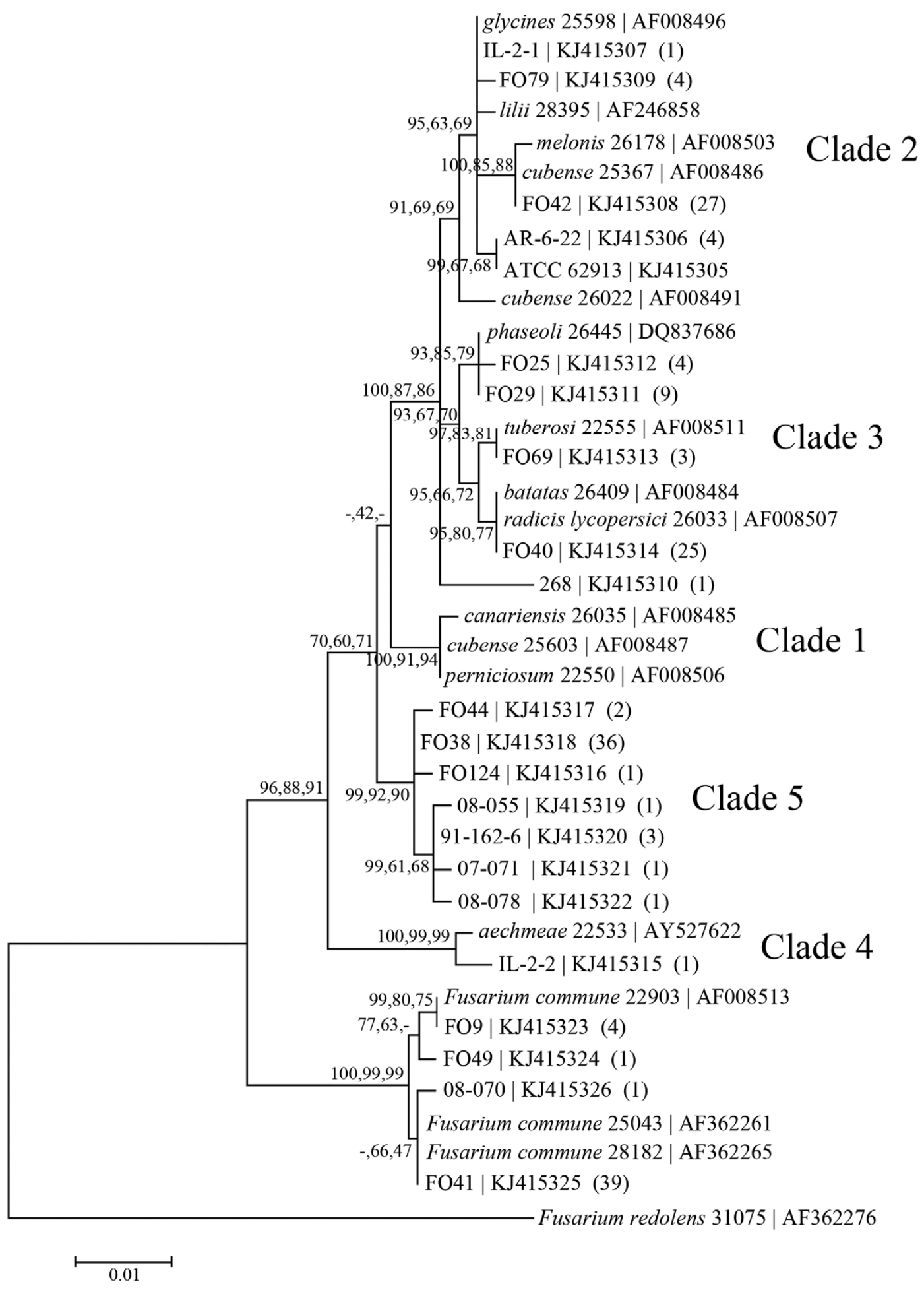

Fig. 3. Maximum likelihood phylogenetic tree of Fusarium oxysporum and F. commune isolates from soybean inferred from the translation elongation factor gene $($ tef $1 \alpha)$ sequence data. Representative sequences collected from the National Center for Biotechnology Information GenBank are followed by their Agricultural Research Service (NRRL) culture collection number. All sequences are followed by their GenBank accessions. The number in parenthesis indicates the number of isolates with the same sequence from this study. The Bayesian posterior probabilities, followed by the bootstrap values for the maximum likelihood and maximum parsimony analyses (1,000 replications) are indicated as percentages in that order at the internodes. F. redolens strain NRRL 31075 was used to root the tree. 
sporum in other hosts have been identified in previous studies $(1,2$, $7,29,32,39,45,56)$ and these studies, along with our study, suggest independent origins for many formae speciales within the FOSC.

TABLE 3. Comparisons of aggressiveness among clades using arcsinetransformed data for disease severity following inoculation of soybean seed with isolates from three clades of Fusarium oxysporum or F. commune

\begin{tabular}{lrr}
\hline Contrast & ATS $^{\mathrm{a}}$ & $P$ value \\
\hline Clade 2 vs. clade 3 & 39.26 & $<0.0001$ \\
Clade 2 vs. clade 5 & 78.18 & $<0.0001$ \\
Clade 2 vs. F. commune & 60.59 & $<0.0001$ \\
Clade 3 vs. clade 5 & 5.52 & 0.0190 \\
Clade 3 vs. F. commune & 2.53 & 0.1117 \\
Clade 5 vs. F. commune & 0.45 & 0.5044 \\
\hline
\end{tabular}

${ }^{a}$ Analysis of variance-type statistic.
The phenotypic data from the $\mathrm{VC}$ analysis also revealed high genetic diversity among FOSC isolates collected from soybean in Iowa. However, the VC analysis also provided little insight into aggressiveness, because approximately two-thirds of the isolates were self-compatible but incompatible with all other isolates. A number of studies have demonstrated that multiple VCGs can exist within formae speciales, especially those with polyphyletic origins $(1,2,7,29,32,39,46,56)$. These studies suggest independent origins for most formae speciales within the FOSC. In a few cases, there is strong evidence that horizontal gene transfer may have contributed to the independent origins of formae speciales $(31,43)$.

Although the clade of an isolate does not clearly indicate its aggressiveness toward soybean, these genotypic traits may still be important in developing disease management strategies, because these "cryptic species" within the FOSC may behave differently

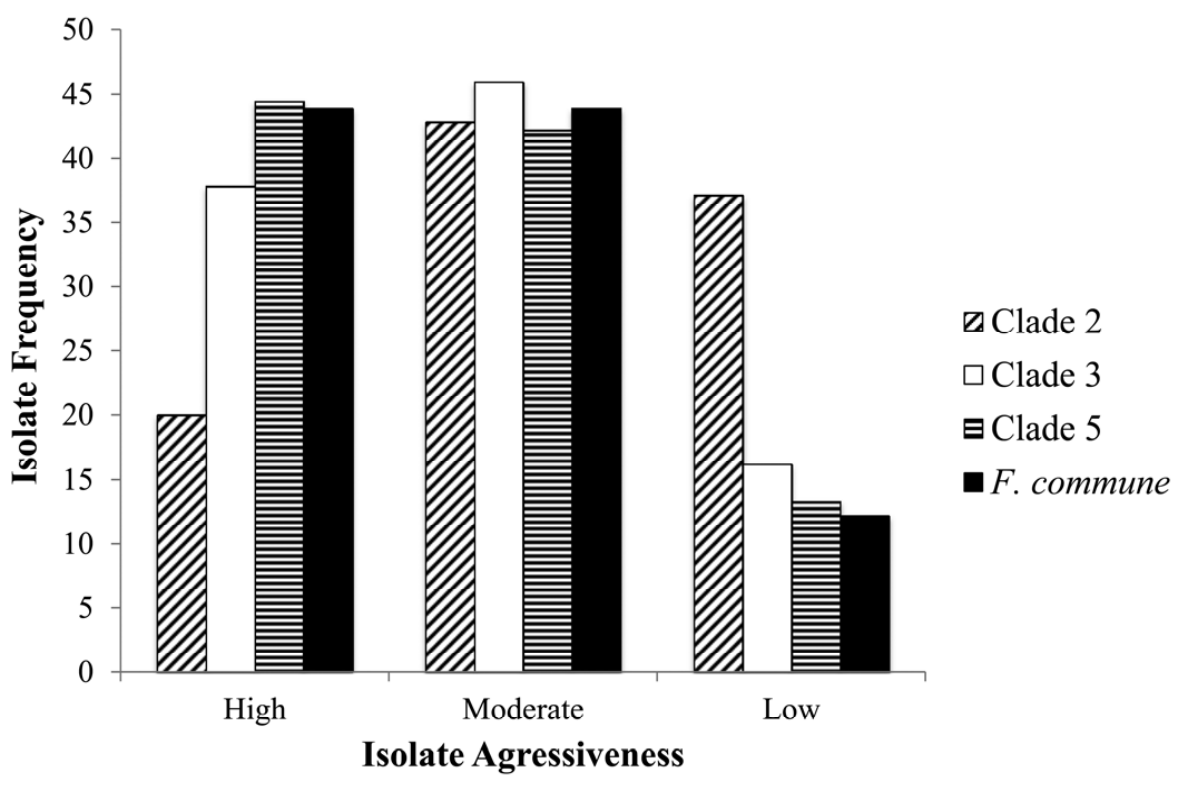

Fig. 4. Frequency of isolates with high, moderate, or low aggressiveness to soybean seedlings among clades of Fusarium oxysporum or F. commune defined by phylogenetic analysis of the translation elongation factor gene and the mitochondrial small subunit sequence data. Isolate aggressiveness was determined by comparing The disease severity index (DSI) for each isolate against that of the check isolates (FO38, FO40, and FO42) using Dunnett's $t$ test at $P=0.05$. Isolates with DSI significantly higher than FO42 were classified as highly aggressive, isolates with DSI significantly lower than FO38 and FO40 were classified as weakly aggressive (low), and isolates with DSI not significantly different from the check isolates were classified as moderately aggressive. Bars represent the means from two experiments with three replications each.

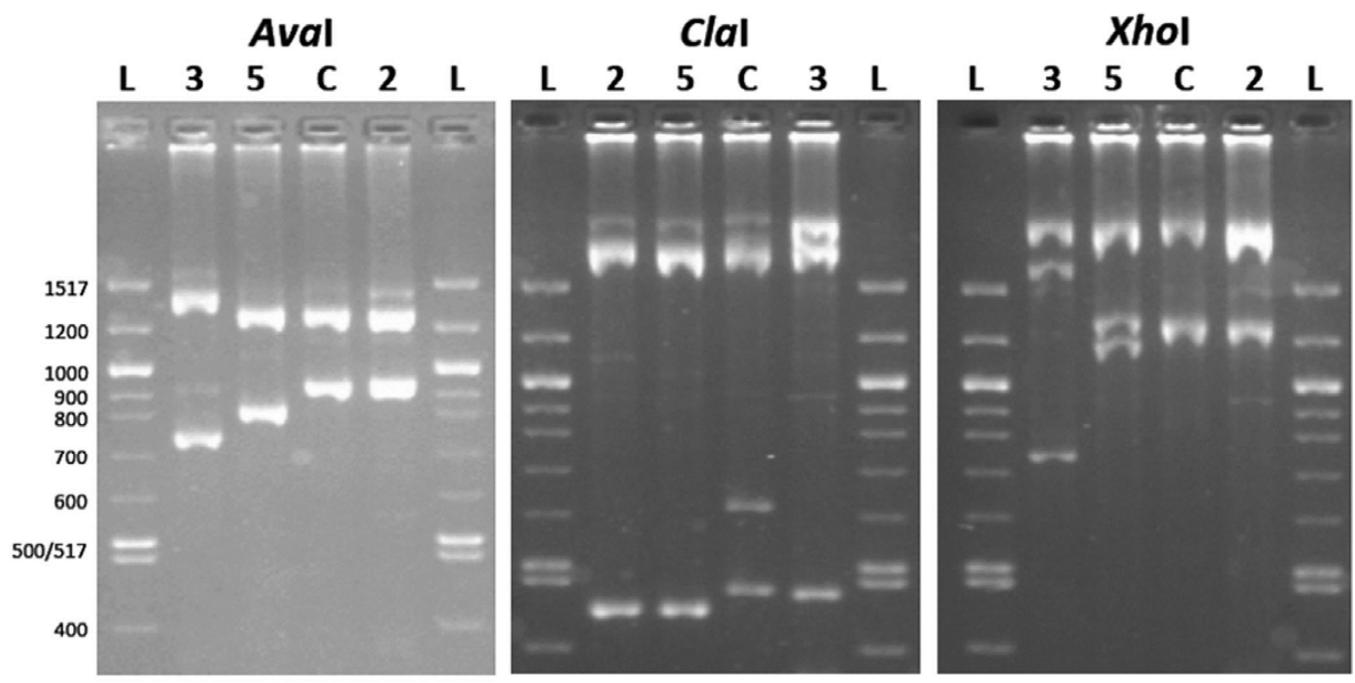

Fig. 5. Most common restriction digest patterns for the intergenic spacer (IGS) region for Fusarium oxysporum and F. commune isolates from soybean using three restriction enzymes AvaI, ClaI, and XhoI. Lane L, 100-bp ladder; lane 2, clade 2; lane 3, clade 3; lane 5, clade 5; and lane C, F. commune. 
to management strategies such as fungicide-seed treatments and host resistance. Recent data suggest that soybean lines exhibit differential reactions to infection by isolates within the FOSC (12). The 128 Iowa isolates included in this study were collected from 55 counties across the state, and there was no geographical pattern to the occurrence of the four clades of $F$. oxysporum, including $F$. commune; isolates from all four clades were evenly distributed throughout Iowa. There were two field locations that had isolates from all four clades, two locations had isolates from three clades, and six locations had isolates from two clades. Consequently, future studies of the population diversity of the FOSC within fields may be important for the development and implementation of management strategies for soybean seedling and root rot diseases.

The PCR-RFLP fingerprinting of the IGS region used in this study provides a quick and easy diagnostic method to determine the clade of an isolate collected from soybean. Most IGS haplotypes could be determined using the restriction enzyme XhoI to separate clades 3 and 5 from clades 2, 4, and F. commune, which had the same restriction pattern for this enzyme. The restriction enzyme ClaI could be used to separate clades 2, 4, and $F$. commune. Isolates in clades 3 and 5 that did not have a restriction site for XhoI could be separated using the restriction enzyme AvaI (Fig. 5). It is important to note that only one soybean isolate belonging to clade 4 was used in the study; therefore, more isolates need to be examined to determine whether the restriction digest patterns are consistent among other isolates belonging to clade 4 .

In Iowa, nine locations had isolates with both MAT loci within the same clade of $F$. oxysporum or $F$. commune. These results suggest that there may be potential for sexual reproduction in soybean fields across Iowa and surrounding states, which could increase genetic diversity of the fungus and its ability to overcome management strategies more quickly. Although asexual reproduction is the only form of reproduction that has been identified for $F$. oxysporum, previous studies have provided evidence that $F$. oxysporum arose from a heterothallic species because only one MAT locus, either the MAT1-1 or MAT1-2, is present in a given isolate $(5,57)$. Using RT-PCR, Yun et al. (57) found that the MAT genes are expressed in $F$. oxysporum, suggesting that they are fully functional. In some cases, sexual reproduction may not occur because the opposite MAT may not be in the same population, other unknown genes may be involved that are no longer functional, or $F$. oxysporum may only undergo sexual reproduction under specific conditions $(5,50,57)$. Previous studies have suggested that one MAT locus is often predominant in a population $(5,22,52)$. In contrast, in one study with $F$. oxysporum f. sp. cubense, both MATs were found and produced sterile sexual-like structures, protoperithecia. It is also important to note that only isolates with opposite MATs in the same clades produced the protoperithecia (19).

Using the rolled-towel assay, we were able to identify high levels of phenotypic diversity in isolate aggressiveness. All isolates used in this study were able to infect and colonize soybean seedlings. However, it is also important to note that the small lesions ( 3 to $10 \mathrm{~mm}$ in length) on soybean seedlings inoculated with weakly aggressive isolates would likely not impede seedling growth. A benefit of using the rolled-towel method is that we were able to test all isolates under the same environmental conditions and at the same inoculum concentration of $1 \times 10^{6}$ conidia/ml. However, because we only tested isolates under a single environmental condition, future studies are needed to determine whether environmental factors such as temperature, moisture, and soil texture influence isolate aggressiveness. Another benefit of the rolled-towel assay is that it is not subject to confounding effects that can occur with organic substrates used as inoculum carriers. In our experiments, we had noninoculated seed in each block that we tested to ensure that other pathogens were not causing similar symptoms on the seedlings. One limitation of the rolled-towel assay is that it does not test for wilt-causing capability. A preliminary greenhouse study using 13 isolates of $F$. oxysporum and 2 isolates of $F$. commune was done to determine their ability to produce vascular wilt. Interestingly, the clade 2 isolate collected from Georgia (ATCC 62913) which was reported to cause wilt on soybean (47) showed very low levels of aggressiveness in the rolled-towel assay (mean DSI of $15.00 \%$ ) but produced high levels of vascular discoloration in the stem tissue in the greenhouse wilt assay (data not shown). Capability to cause vascular wilt symptoms should be tested for other isolates in clade 2 with low aggressiveness in the rolled-towel assay. This information will provide additional insight into diversity within the FOSC isolated from soybean.

\section{ACKNOWLEDGMENTS}

This project was funded by the Iowa Soybean Association. We thank M. Díaz Arias, B. Linn, M. V. de Sousa, H. Simmons, and M. Beattie for technical assistance and cooperation in this study; A. Kriss for her assistance with the statistical analysis; and A. Dorrance (Ohio Agricultural Research and Development Center, Wooster), A. Fakhoury (Southern Illinois University, Carbondale), D. Malvick (University of Minnesota, St. Paul), and B. Nelson (North Dakota State University, Fargo) for providing isolates from neighboring states.

\section{LITERATURE CITED}

1. Abo, K., Klein, K. K., Edel-Hermann, V., Gautheron, N., Traore, D., and Steinberg, C. 2005. High genetic diversity among strains of Fusarium oxysporum f. sp. vasinfectum from cotton in Ivory Coast. Phytopathology 95:1391-1396.

2. Alves-Santos, F. M., Benito, E. P., Eslava, A. P., and Díaz-Mínguez, J. M. 1999. Genetic diversity of Fusarium oxysporum strains from common bean fields in Spain. Appl. Environ. Microbiol. 65:3335-3340.

3. Appel, D. J., and Gordon, T. R. 1995. Intraspecific variation within populations of Fusarium oxysporum based on RFLP analysis of the intergenic spacer region of the rDNA. Exp. Mycol. 19:120-128.

4. Appel, D. J., and Gordon, T. R. 1996. Relationships among pathogenic and nonpathogenic isolates of Fusarium oxysporum based on the partial sequence of the intergenic spacer region of the ribosomal DNA. Mol. Plant-Microbe Interact. 9:125-138.

5. Arie, T., Kaneko, I., Yoshida, T., Noguchi, M., Nomura, Y., and Yamaguchi, I. 2000. Mating-type genes from asexual phytopathogenic ascomycetes Fusarium oxysporum and Alternaria alternata. Mol. PlantMicrobe Interact. 13:1330-1339.

6. Armstrong, J. K., and Armstrong, G. M. 1958. A race of the cotton-wilt Fusarium causing wilt of Yelredo soybean and flue-cured tobacco. Plant Dis. Rep. 42:147-151.

7. Baayen, R. P., O’Donnell, K., Bonants, P. J. M., Cigelnik, E., Kroon, L. P. N. M., Roebroeck, E. J. A., and Waalwijk, C. 2000. Gene genealogies and AFLP analyses in the Fusarium oxysporum complex identify monophyletic and nonmonophyletic formae speciales causing wilt and rot disease. Phytopathology 90:891-900.

8. Backmand, T. Smith, K., and Schawalbe, K. 1993. Soybean Diagnostic Guide. American Soybean Association, St. Louis.

9. Bienapfl, J. C. Fusarium and Phytophthora species associated with root rot of soybean (Glycine max). 2011. Ph.D. thesis, University of Minnesota, St. Paul.

10. Broders, K. D., Lipps, P. E., Paul, P. A., and Dorrance, A. E. 2007. Evaluation of Fusarium graminearum associated with corn and soybean seed and seedling disease in Ohio. Plant Dis. 91:1155-1160.

11. Correll, J. C., Klittich, C. J. R., and Leslie, J. F. 1987. Nitrate nonutilizing mutants of Fusarium oxysporum and their use in vegetative compatibility tests. Phytopathology 77:1640-1646.

12. Cruz, D., Ellis, M. L., Leandro, L. F., and Munkvold, G. P. 2013. Characterization of the interaction between soybean cultivars and isolates of Fusarium oxysporum causing seedling disease. (Abstr.) Phytopathology. 103:S2.31.

13. Díaz Arias, M. M., Leandro, L. F., and Munkvold, G. P. 2013. Aggressiveness of Fusarium species and impact of root infection on growth and yield of soybeans. Phytopathology 103:822-832.

14. Díaz Arias, M. M., Munkvold, G. P., Ellis, M. L., and Leandro, L. F. S. 2013. Distribution and frequency of Fusarium species associated with soybean roots in Iowa. Plant Dis. 97:1557-1562.

15. Ellis, M. L., Broders, K. D., Paul, P. A., and Dorrance, A. E. 2011. 
Infection of soybean seed by Fusarium graminearum and effect of seed treatments on disease under controlled conditions. Plant Dis. 95:401-407.

16. Ellis, M. L., Díaz Arias, M. M., Cruz Jiménez, D. R., Munkvold, G. P., and Leandro, L. F. 2012. First report of Fusarium commune causing damping-off, seed rot, and seedling root rot on soybean (Glycine max) in the United States. Plant Dis. 97:284.

17. Farias, G. M., and Griffin, G. J. 1990. Extent and patterns of early soybean seedling colonization by Fusarium oxysporum and F. solani in naturally infested soil. Plant Soil 123:59-65.

18. Felsenstein, J. 1985. Confidence limits on phylogenies: An approach using the bootstrap. Evolution 6:227-242.

19. Fourie, G., Steenkamp, E. T., Gordon, T. R., and Viljoen, A. 2009 Evolutionary relationship among the Fusarium oxysporum f. sp. cubense vegetative compatibility groups. Appl. Environ. Microbiol. 75:4770-4781.

20. Fujinaga, M., Ogiso, H., Shinohara, H., Tsushima, S., Nishimura N., Togowa, M., Saito, H., and Nosue, M. 2005. Phylogenetic relationships between the lettuce root rot pathogen Fusarium oxysporum f. sp. lactucae race 1,2 , and 3 based on the sequence of the intergenic spacer region of its ribosomal DNA. J. Gen. Plant Pathol. 71:402-407.

21. Huelsenbeck, J. P., and Ronquist, F. 2001. MRBAYES 3: Bayesian phylogenetic inference under mixed models. Bioinformatics 19:1572-1574.

22. Irzykowska, L., Bocianowski, J., Waśkiewicz, A., Weber, Z., Karolewski, Z., Goliński, P., Kostecki, M., and Irzykowski, W. 2012. Genetic variation of Fusarium oxysporum isolates forming fumoninsin B1 and moniliformin. J. Appl. Genet. 53:237-247.

23. Jiménez-Gasco, M. M., Navas-Cortés, J. A., and Jiménez- Díaz, R. M. 2004. The Fusarium oxysporum f. sp. ciceris/Cicer arietinum pathosystem: A case study of the evolution of plant-pathogenic fungi into races and pathotypes. Int. Microbiol. 7:95-104.

24. Killebrew, J. F., Roy, K. W., and Abney, T. S. 1993. Fusaria and other fungi on soybean seedlings and roots of older plants and interrelationships among fungi, symptoms, and soil characteristics. Can. J. Plant Pathol. 15:139-146.

25. Kimura, M. 1980. A simple method for estimating evolutionary rate of base substitutions through comparative studies of nucleotide sequences. J. Mol. Evol. 16:111-120.

26. Kistler, H. C. 1997. Genetic diversity in the plant-pathogenic fungus Fusarium oxysporum. Phytopathology 87:474-479.

27. Laurence, M. H., Burgess, L. W., Summerell, B. A., and Liew, E. C. Y. 2012. High levels of diversity in Fusarium oxysporum from noncultivated ecosystems in Australia. Fungal Biol. 116:289-297.

28. Leslie, J. F., and Summerell, B. A. 2006. The Fusarium Laboratory Manual. Blackwell Publishing, Oxford.

29. Lievens, B., Rep, M., and Thomma, B. P. H. J. 2007. Recent developments in the molecular discrimination of formae speciales of Fusarium oxysporum. Pest Manage. Sci. 64:781-788.

30. Little, T. M., and Hills, F. J. 1978. Agricultural Experimentation, Design and Analysis. John Wiley \& Sons, New York.

31. Ma, L. J., van der Does, H. C., Borkovich, K. A., Coleman, J. J., Daboussi, M. J., Di Pietro, A., Dufresne, M., Freitag, M., Grabherr, M., Henrissat, B., Houterman, P. M., Kang, S., Shim, W. B., Woloshuk, C., Xie, X. H., Xu, J. R., Antoniw, J., Baker, S. E., Bluhm, B. H., Breakspear, A., Brown, D. W., Butchko, R. A. E., Chapman, S., Coulson, R., Coutinho, P. M., Danchin, E. G. J., Diener, A., Gale, L. R., Gardiner, D. M., Goff, S., Hammond-Kosack, K. E., Hilburn, K., Hua-Van, A., Jonkers, W., Kazan, K., Kodira, C. D., Koehrsen, M., Kumar, L., Lee, Y. H., Li, L. D., Manners, J. M., Miranda-Saavedra, D., Mukherjee, M., Park, G., Park, J., Park, S. Y., Proctor, R. H., Regev, A., Ruiz-Roldan, M. C., Sain, D., Sakthikumar, S., Sykes, S., Schwartz, D. C., Turgeon, B. G., Wapinski, I., Yoder, O., Young, S., Zeng, Q. D., Zhou, S. G., Galagan, J., Cuomo, C. A., Kistler, H. C., and Rep, M. 2010. Comparative genomics reveals mobile pathogenicity chromosomes in Fusarium. Nature 464:367-373.

32. Mbofung, G. Y., Hong, S. G., and Pryor, B. M. 2007. Phylogeny of Fusarium oxysporum f. sp. lactucae inferred from mitochondrial small subunit, elongation factor $1-\alpha$, and nuclear ribosomal intergenic spacer sequence data. Phytopathology 97:87-98.

33. Nelson, B. D. 1999. Fusarium blight or wilt, root rot, and pod and collar rot. Pages 35-36 in: Compendium of Soybean Diseases, 3rd ed. American Phytopathological Society Press, St. Paul, MN.

34. Nei, M., and Kumar, S. 2000. Molecular Evolution and Phylogenetics. Oxford University Press, New York.

35. Nogales Moncanda, A. M., Jiménez Díaz, R. M, and Pérez Artés, E. 2009. Vegetative compatibility groups in Fusarium oxysporum f. sp. ciceris and F. oxysporum non-pathogenic to chickpea. J. Phytopathol. 157:729-735.

36. O'Donnell. 1992. Ribosomal DNA internal transcribed spacers are highly divergent in the phytopathogenic ascomycete Fusarium sambucinum (Gibberella pulicaris). Curr. Genet. 22:213-220.

37. O'Donnell, K., Gherbawy, Y., Schweigkofler, W., Adler, A., and Prillinger, H. 1999. Phylogenetic analyses of DNA sequence and RAPD data compared in Fusarium oxysporum and related species from maize.
J. Phytopathol. 147:445-452.

38. O’Donnell, K., Gueidan, C., Sink, S., Johnston, P. R., Crous, P. W., Glenn, A., Riley, R., Zitomer, N. C., Colyer, P., Waalwijk, C., van der Lee, T., Moretti, A., Kang, S., Kim, H.-S., Geiser, D. M., Juba, J. H., Baayen, R. P., Crome, M. G., Bithell, S., Sutton, D. A., Skovgaard, K., Ploetz, R., Kistler, H. C., Elliott, M., Davis, M., and Sarver, B. A. J. 2009. A twolocus DNA sequence database for typing plant and human pathogens within the Fusarium oxysporum species complex. Fungal Genet. Biol. 46:936-948.

39. O’Donnell, K., Kistler, H. C., Cigelnik, E., and Ploetz, R. C. 1998 Multiple evolutionary origin of the fungus causing Panama disease of banana; concordant evidence from nuclear and mitochondrial gene genealogies. Proc. Natl. Acad. Sci. USA 95:2044-2049.

40. O'Donnell, K., Sutton, D. A., Rinaldi, M. G., Magnon, K. C., Cox, P. A., Revankar, S. G., Sanche, S., Geiser, D. M., Juba, J. H., van Burik, J.-A. H., Walsh, T. J., Francesconi, A., Anaissie, E. J., Padhye, A., and Robinson, J. S. 2004. Genetic diversity of human pathogenic members of the Fusarium oxysporum complex inferred from gene genealogies and AFLP analyses: Evidence for the recent dispersion of a geographically widespread clonal lineage and nosocomial origin. J. Clin. Microbiol. 42:5109-5120

41. Pedersen, P. 2004. Soybean growth and development. Iowa State Univ. Ext. Publ. PM 1945. Ames.

42. Price, E. W., and Carbone, I. 2005. SNAP: Workbench management tool for evolutionary population genetic analysis. Bioinformatics 21:402-404.

43. Ramos, B., Alves-Santos, F. M., García-Sánchez, M. A., Martín-Rodrigues, N., Eslava, A. P., and Díaz-Mínguez, J. M. 2007. The gene coding for a new transcription factor ( $f t f l$ ) of Fusarium oxysporum is only expressed during infection of common bean. Fungal Genet. Biol. 44:864-876.

44. Rizvi, S. A. A., and Yang, X. B. 1996. Fungi associated with soybean seedling disease in Iowa. Plant Dis. 80:57-60.

45. Skovgaard, K., Nirenberg, H. I., O’Donnell, K., and Rosendahl, S. 2001. Evolution of Fusarium oxysporum f. sp. vasinfectum races inferred from multigene genealogies. Phytopathology 91:1231-1237.

46. Skovgaard, K., Rosendahl, S., O'Donnell, K., and Nirenberg, H. I. 2003. Fusarium commune is a new species identified by morphological and molecular phylogenetic data. Mycologia 95:630-636.

47. Sumner, D. R., and Minton, N. A. 1987. Interaction of Fusarium wilt and nematodes in Cobb soybean. Plant Dis. 71:20-23.

48. Tamura, K. 1992. Estimation of the number of nucleotide substitutions when there are strong transition-transversion and $\mathrm{G}+\mathrm{C}$-content biases. Mol. Biol. Evol. 9:678-687.

49. Tamura, K., Peterson, D., Peterson, N., Stecher, G., Nei, M., and Kumar, S. 2011. MEGA5: Molecular evolutionary genetics analysis using maximum likelihood, evolutionary distance, and maximum parsimony methods. Mol. Biol. Evol. 28:2731-2739.

50. Taylor, J. W., Jacobson, D. J., and Fisher, M. C. 1999. The evolution of asexual fungi: Reproduction, speciation and classification. Annu. Rev. Phytopathol. 37:197-246.

51. Thompson, J. D., Higgins, D. G., and Gibson, T. J. 1994. CLUSTAL W: Improving the sensitivity of progressive multiple sequence alignment through sequence weighting, positions-specific gap penalties and weight matrix choice. Nucleic Acids Res. 22:4673-4680.

52. Vega-Bartol, J. J., Martín-Dominguez, R., Ramos, B., García-Sánchez, M.-A., and Díaz-Mínguez, J. M. 2011. New virulence groups in Fusarium oxysporum f. sp. phaseoli: The expression of the gene coding for the transcription factor ftf1 correlates with virulence. Phytopathology 101:470479.

53. Vincze, T., Posfai, J., and Roberts, R. J. 2003. NEBcutter: A program to cleave DNA with restriction enzymes. Nucleic Acids Res. 31:3688-3691.

54. White, T. J., Bruns, T. Lee, S., and Taylor, J. 1990. Amplification and direct sequencing of fungal ribosomal RNA genes for phylogenetics. Pages 315-322 in: PCR Protocols: A Guide to Methods and Amplifications. M. A. Innis, D. H. Gelfand, J. J. Sninsky, and T. J. White, eds. Academic Press, Inc., San Diego, CA

55. Wolfinger, R. D., Federer, W. T., and Cordero-Brana, O. 1997. Recovering information in augmented designs, using SAS PROC GLM and PROC MIXED. Agron. J. 89:856-859.

56. Wong, J. Y., and Jeffries, P. 2006. Diversity of pathogenic Fusarium populations associated with asparagus roots in decline soils in Spain and the UK. Plant Pathol. 55:331-342.

57. Yun, S. H., Arie, T., Kaneko, I., Yoder, O. C., and Turgeon, B. G. 2000. Molecular organization of mating type loci in heterothallic, homothallic, and asexual Gibberella/Fusarium species. Fungal Genet. Biol. 31:7-20.

58. Zamani, M. R., Motallebi, M., and Rostamian, A. 2004. Characterization of Iranian isolates of Fusarium oxysporum on the basis of RAPD analysis, virulence and vegetative compatibility. J. Phytopathol. 152:449-453.

59. Zelaya-Molina, L. X., Ortega M. A., and Dorrance, A. E. 2011. Easy and efficient protocol for oomycete DNA extraction suitable for population genetic analysis. Biotechnol. Lett. 33:715-720. 